\title{
GEOTECHNICAL INVESTIGATIONS FOR THE FOUNDATION INVESTIGATIONS AT THE CROSS DRAINAGE STRUCTURES ALONG THE CANAL ALIGNMENT FOR THE PONNAIYAR- PALAR INTRA STATE LINK CANAL PROJ ECT
}

Shahid Noor ${ }^{1}$, Dr. R. Chitra ${ }^{2}$, Dr. Manish Gupta ${ }^{3}$ and Dr. Amardeep Singh ${ }^{4}$

\begin{abstract}
Rainfall is the important element of Indian economy. Although the monsoons effect most part of India, the amount of rainfall varies from heavy to scanty on different parts. There is great regional and temporal variation in the distribution of rainfall. Over $80 \%$ of the annual rainfall is received in the four rainy months of June to September. The average annual rainfall is about $125 \mathrm{~cm}$, but it has great spatial variations. This lead to excess rainfall in one region which results the flood and water shortage in other region which leads to the drought in other region. The interlinking project are envisaged with aim to transfer the water from the water surplus region the water deficit region. The Ponnaiyar (Nedungal Anicut) - Palar Intrastate Link Project of Tamil Nadu envisages diversion of $99 \mathrm{Mm}^{3}$ of flood water of Ponnaiyar river available at Krishnagiri dam to the Palar River. The main objective of the link Project is to improve the Groundwater potential to stabilize the existing command area and stabilize the enroute command areas of Tamil Nadu state. The geotechnical investigation for the proposed Ponnaiyar (Nedungal Anicut) - Palar Intra-state Link Project was undertaken by CSMRS. The paper presents the foundation investigations carried out for the CD structures proposed along the canal alignment of the proposed link canal..

Key Words: Geotechnical Investigations, Borrow Area Investigations, Foundation Investigations, Trial Pits, Shear, Link Canal, Compaction, Consolidation
\end{abstract}

Disclaimer: The views expressed in this paper are strictly individual views of the author and do not, in any way, represent the views of the department/organization where they are presently working.

\footnotetext{
${ }^{1}$ Scientist ' $C$ ', Central Soil and Materials Research Station, Ministry of Water Resources, $R D \&$ GR, Government of India, Olof Palme Marg, Hauz Khas, New Delhi-110016.

${ }^{2}$ Scientist ' $E$ ', Central Soil and Materials Research Station, Ministry of Water Resources, RD \& GR, Government of India, Olof Palme Marg, Hauz Khas, New Delhi-110016.

${ }^{3}$ Scientist ' $D$ ', Central Soil and Materials Research Station, Ministry of Water Resources, RD \& GR, Government of India, Olof Palme Marg, Hauz Khas, New Delhi-110016.

${ }^{4}$ Scientist ' $C$ ', Central Soil and Materials Research Station, Ministry of Water Resources, $R D \& \&$ G, Government of India, Olof Palme Marg, Hauz Khas, New Delhi-110016.
} 


\section{INTRODUCTION}

India is a vast country and is highly diversified in terms of natural resources and socio-economic setup. Moreover, its water resources are unevenly distributed in space and time. With increasing population and increasing aspiration for improved standard of living, there is an acute pressure on the demand and availability of water. In India, the river-linking project in a sensible and scientific manner will not only allow the prevention of the colossal wastage of a vitally important natural resource, flood and inundation by detaining flowing surface water of rainy seasons, but also ensure availability of water to drier areas, combating both flood and drought simultaneously. Moreover, it will generate 34,000 MW of hydropower and irrigation to an additional 35 million hectares (135,135 square miles) of land (Sharon Gourdji, Carrie Knowlton \& Kobi Platt).

\section{INTERLINKING OF RIVERS IN INDIA}

Human societies have always tried to expand the spatial extent of availability of water by the diversion of streams or rivers. The idea of drawing water from the rivers in eastern India, which have larger run-off, in comparison to certain places in the peninsular region, where the precipitation levels are much lower, can be seen as an extension of that practice.

The country receives about 4,000 $\mathrm{cu} \mathrm{km}$ of water as precipitation annually. However, unlike the precipitation patterns in the temperate regions of the world, precipitation in India is characterized by acute variations in both space and time. A large part of the total precipitation on the country is received in the Himalayan catchments of the Ganga and Brahmaputra rivers. The distribution of precipitation over India is predominantly governed by the Monsoon, as a result of which the northeastern quarter of the country receives substantially larger precipitation, in comparison with the northwestern, western and southern parts. Though the west-flowing rivers originating from the Western Ghats have substantial runoff, the spatial scope for their wider utilization is limited (Upali A. Amarasinghe et.al).

For assessing the water resources of India, the area of the country has been divided in 24 river-basins in which the west flowing rivers from the Western Ghats have all been clubbed as one. On the basis of the National Perspective on water resource development, the interlinking project has two components - the Himalayan and the Peninsular (NWDA web site). The Himalayan component includes construction of storage dams on the main tributaries of Ganga and Brahmaputra to transfer 'surplus' water to the west. The Peninsular component involves connecting rivers like Godavari and Mahanadi that have 'surplus' water with rivers like Krishna and Cauvery. A total of 31 link are envisaged, out of which 14 links will be in the Himalayan component and 17 links will be in the Peninsular component (Figure 1).

\section{Ponnaiyar - Palar Intra State Link Canal Project}

The Ponnaiyar (Nedungal Anicut) - Palar Intra-State Link Project, Tamil Nadu envisages diversion of 99 $\mathrm{Mm}^{3}$ of flood flows/spill waters of Ponnaiyar river available at Krishnagiri dam from the existing Nedungal Anicut, located at $16 \mathrm{~km}$ downstream of Krishnagiri Dam, to the Palar River. The main objective of the link canal project is to improve the groundwater potential for stabilizing the existing command area to an extent of 9500 ha. which is presently being irrigated through open wells and bore wells in water-short Vaniyambadi taluk of Vellore district in Palar basin, besides feeding enroute system 
tanks (Eris) for stabilising the enroute command areas in Krishnagiri and Vellore districts of Tamil Nadu state. Out of the above, a quantum of about $3.882 \mathrm{Mm}^{3}$ of water is planned for domestic water supply to enroute villages for about 1.52 lakh population (CSMRS Report 2005).

The Ponnaiyar (Nedungal Anicut ) - Palar Link Canal off-takes from the left bank of the existing Nedungal Anicut at FSL $434.450 \mathrm{~m}$ and outfalls at $419.666 \mathrm{~m}$ into Kal Ar of Godd Ar, which is a tributary of Palar river near Natrampalli village of Vaniyambadi Taluk. The total length of the link canal is $54.15 \mathrm{~km}$. The canal passes by gravity through Pochampalli \& Krishnagiri taluks of Krishnagiri district and Tirupattur taluk of Vellore district of Tamil Nadu.

The canal is designed as unlined trapezoidal section to carry a designed discharge of 68 cumecs with a uniform bed width of $25.0 \mathrm{~m}$ and full supply depth of $2.45 \mathrm{~m}$. Uniform bed slope of 1:4500 is adopted for the entire length of the link canal. The link canal crosses $62 \mathrm{CD} / \mathrm{CM}$ structures enroute including one head regulator at off-take point and one out-fall structure at tail end.

The main features and cross drainage structures along the canal alignment of proposed Ponnaiyar (Nedungal Anicut) - Palar Intra State Link Canal Project, Tamil Nadu are given in Table 1 a \& 1 b.

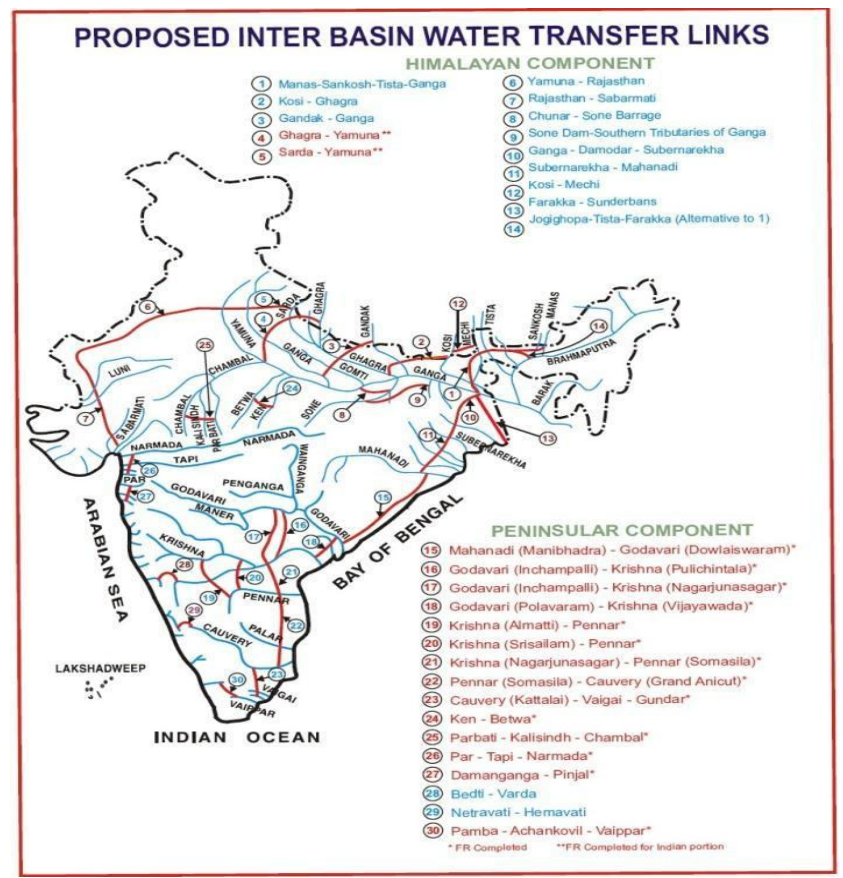

Figure 1 Proposed Interlinking of Rivers Projects in India

\section{Benefits from the Project}

The Ponnaiyar (Nedungal Anicut) - Palar Intra-state Link Project of Tamil Nadu is planned as a multipurpose project with flood control, water supply and irrigation benefit in the downstream of Krisnagiri dam. The project is planned to divert the $99 \mathrm{Mm} 3$ of flood flows/spill waters of Ponnaiyar river available at Krishnagiri dam at 50\% dependability from the existing Nedungal Anicut, located at 16 $\mathrm{km}$ downstream of Krishnagiri Dam, to the Palar River. The project will improve the groundwater potential and will stabilize the existing command area to an extent of 9500 ha which is presently being 
irrigated through open wells and bore wells in water-short Vaniyambaditaluk of Vellore district in Palar basin apart from feeding enroute system tanks (Eris) for stabilizing the enroute command areas in Krishnagiri and Vellore districts of Tamil Nadu state. A quantum of about 3.882 Mm3 of water is planned for domestic water supply to enroute villages for about 1.52 lakh population.

Table 1a : Main Features of the Link Canal

\begin{tabular}{|l|l|l|}
\hline $\begin{array}{l}\text { S. } \\
\text { No }\end{array}$ & Feature & Characteristics \\
\hline 1 & Length of the canal & $54.15 \mathrm{~km}$ \\
\hline 2 & Shape/type of canal & $\begin{array}{l}\text { Trapezoidal } \\
\text { Unlined canal }\end{array}$ \\
\hline 3 & FSL at Off-take & $+434.450 \mathrm{~m}$ \\
\hline 4 & $\begin{array}{l}\text { Bed slope of the } \\
\text { canal }\end{array}$ & 1 in 4500 \\
\hline 5 & $\begin{array}{l}\text { Full supply depth } \\
\text { (FSD) }\end{array}$ & $2.45 \mathrm{~m}$ \\
\hline 6 & $\begin{array}{l}\text { FSL at Outfall } \\
+419.666 \mathrm{~m}\end{array}$ \\
\hline 7 & $\begin{array}{l}\text { Bed width of the } \\
\text { canal }\end{array}$ & $25 \mathrm{~m}$ \\
\hline 8 & $\begin{array}{l}\text { Side slopes of the } \\
\text { canal }\end{array}$ & $1.5 \mathrm{H}: 1 \mathrm{~V}$ \\
\hline 9 & $\begin{array}{l}\text { Maximum carrying } \\
\text { capacity of the canal }\end{array}$ & 68 cumec \\
\hline 10 & $\begin{array}{l}\text { Major Rivers } \\
\text { crossed by link } \\
\text { canal }\end{array}$ & $\begin{array}{l}\text { Mattur } \\
\text { Velakkan Ar and } \\
\text { Ar. }\end{array}$ \\
\hline
\end{tabular}

Table $1 \mathrm{~b}$ : Cross Drainage structures along the Canal Alignment

\begin{tabular}{|l|l|l|}
\hline S. No. & Feature & Nos. \\
\hline 1 & Head Regulator at Off take & 1 No. \\
\hline 2 & $\begin{array}{l}\text { CR cum Escape at RD } \\
29.55 \mathrm{~km} \text { at Bargur Ar.pe }\end{array}$ & 1 No. \\
\hline 3 & CR/Outfall Structure & 1 No. \\
\hline 4 & Aqueducts & 6 Nos. \\
\hline 5 & Canal Syphon & 6 Nos. \\
\hline 6 & Super Passages & 2 Nos. \\
\hline 7 & SLRB & 16 Nos. \\
\hline 8 & DLRB & 18 Nos. \\
\hline 9 & Outlets & 5 Nos. \\
\hline 10 & Undertunnels & 5 Nos. \\
\hline 11 & Elevated pipes/trough & 1 No. \\
\hline Total & & 62 Nos. \\
\hline
\end{tabular}

\section{Topography and Geology of the Project Area}

The link canal project including its command area falls in the basins of the Krishna and Pennar. The topography and geology of these basins is may be studied in two parts

\section{Krishna basin}

The Krishna basin is bounded on the north by the common ridge separating it from Godavari basin, on the south and east by the Eastern Ghats and on the west by Western Ghats. Except the hills forming the watershed round the basin, the entire drainage basin of the river comprises of rolling and undulating country and a series of ridges and valleys interspersed with low hill ranges. The interior of the basin in its middle reaches is a plateau, the greater part of which is at an elevation of 300 to $600 \mathrm{~m}$. Its general slope is eastwards. Great undulating plains divided from each other by flat topped ranges of hills are the chief characteristics of this plateau. The Krishna basin consists largely of Archaean formations, part of which are covered by Deccan trap lavas, Cuddapah and Vindhyan series and faulted blocks of Gondwanas (NWDA website). 


\section{Palar Basin}

The upper reaches of the basin is predominantly covered by granite gneisses, Gondwanas, Cuddapah formations of Archaeans belonging to Dharwarian system with basic intrusives. The central portion of the catchment is covered by archaean crystalline hard rock and sedimentary rocks. Alluvial deposits are found all along the coastal belt and Palar River course comprising of marine and riverine deposits. Due to uplift of landmasses and tactonic activities, the archaean dharwarian hard rocks were subjected to deformation into folds and faults and also resulted in shifting of river courses in basin area (NWDA website).

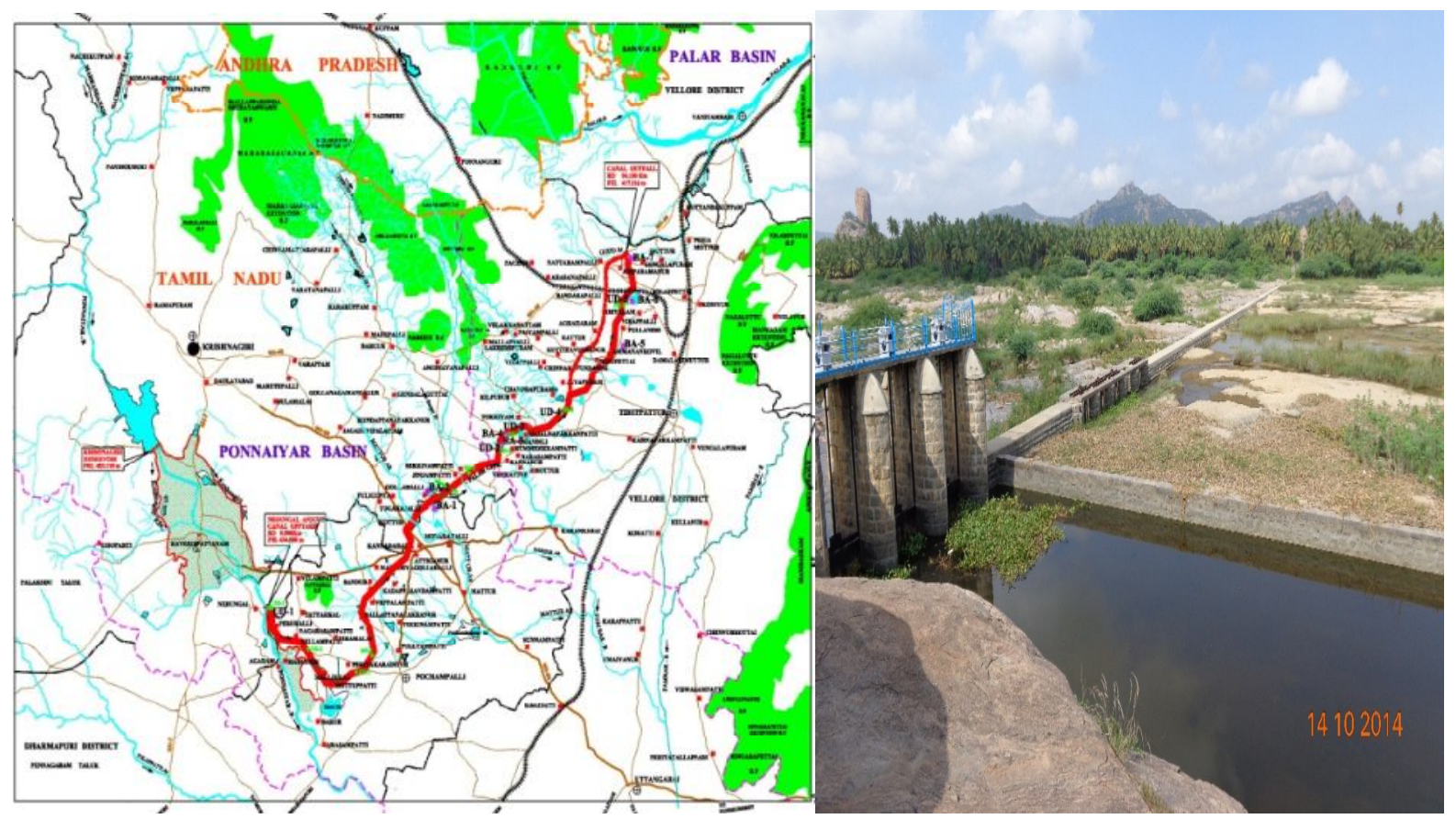

(a)

(b)

Figure 2: (a)Index Map of the Ponnaiyar (Nedungal Anicut) - Palar Intra-State Link Project \& (b) off take point of Canal

\section{GEOTECHNICAL INVESTIGATIONS}

The geotechnical investigations involve foundation investigations at the major and minor drainage works, soil investigations along the canal alignment and borrow area investigations. The foundation investigations at major cross drainage/cross masonry structures sites involve drilling the drill hole on each side of cross drainage structure and the Standard Penetration test and insitu Permeability test beside the collection of undisturbed/representative soil samples in shelby tubes at regular intervals.

The soil investigation works along the canal alignment involves collection of undisturbed/ disturbed soil samples from the trial pits excavated at the regular intervals of 4 to $5 \mathrm{~km}$ along the canal alignment. 
The undisturbed soil samples are collected in core cutters from shallow pits of size $3 \mathrm{~m} \times 3 \mathrm{~m} \times 3 \mathrm{~m}$ from the portion where the canal is in cutting and the representative disturbed soil samples are to collected in the gunny bags from the surrounding areas (borrow area) where the canal is in filling.

A total of 62 cross drainage/cross masonry structures fall along the canal aligment. Figure 2 (a) shows the index map of the Ponnaiyar (NedungalAnicut) - Palar Intra-state Link Project. The proposed canal is $54.15 \mathrm{~km}$ long which off takes from the left bank of the existing NedungalAnicut \{Figure 2(b) $\}$ at FSL $434.450 \mathrm{~m}$ and outfalls at $419.666 \mathrm{~m}$ into KalAr of GoddAr, which is a tributary of Palar river near Natrampalli village of Vaniyambaditaluk. The canal passes by gravity through Pochampalli \& Krishnagiritaluks of Krishnagiri district and Tirupatturtaluk of Vellore district of Tamil Nadu. During its traverse, the canal crosses the rivers MatturAr, BargurAr and Velakkanattam Ar.

The longitudinal section of the proposed canal indicate that most of the canal alignment falls in the cutting portion barring few exceptions from RD $15.323 \mathrm{~km}$ to $21.825 \mathrm{~km}$, from RD $23.000 \mathrm{~km}$ to 26.500 $\mathrm{km}$, at RD $29.581 \mathrm{~km}$, from RD $33.000 \mathrm{~km}$ to $34.000 \mathrm{~km}$. and from RD $39.3060 \mathrm{~km}$ to $40.076 \mathrm{~km}$.

\section{SOIL INVESTIGATION AT THE CROSS DRAINAGE STRUCTURES}

\section{FIELD INVESTIGATIONS}

A total of 14 bore holes were drilled along the canal alignment at the site of cross drainage structures. Out of 14 bore holes , 2 bore hole were drilled at the canal off take point, one bore hole at canal out fall point and remaining 11 bore holes at the points where the canal encounters the CD/CM structure. The depth of bore holes varies from $6.0 \mathrm{~m}$ to $17.0 \mathrm{~m}$. The logs of bore holes BH- 6 \& BH-11 are presented in Figure 2 (a) \& (b). 


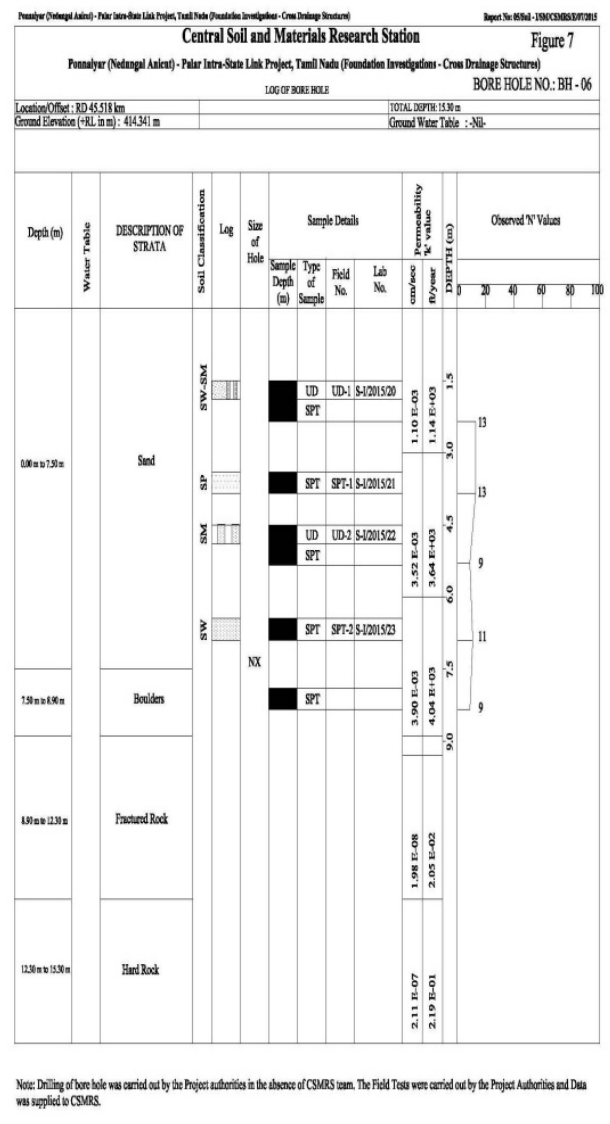

(a)

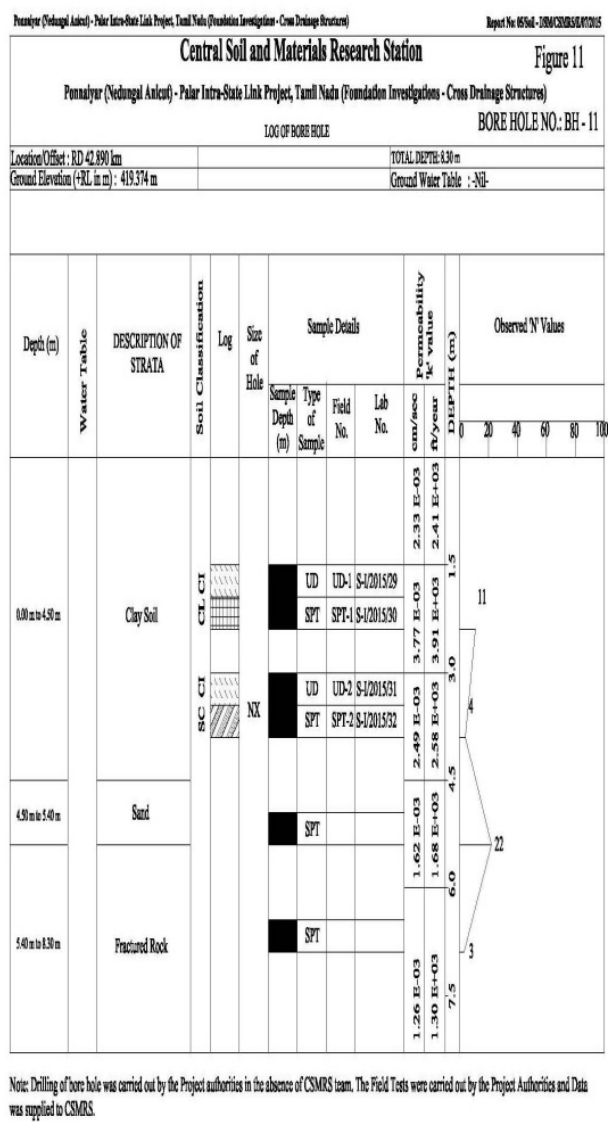

(b)

Figure 2: Log of Bore Holes (a) BH-6 (b) BH-11

The water table was encountered only in two bore holes at the location of Canal Head Regulator at off take point and was recorded at $1.75 \mathrm{~m}$ depth and $2.40 \mathrm{~m}$ depth. A total of 43 SPT and 57 insitu permeability test were conducted. The SPT values in 11 bore were observed more than 50 and in remaining 3 bore holes, the SPT values vary from 3 to 14 . The SPT values observed in few bore holes are presented in Table 2. The permeability of strata along the canal alignment vary from pervious to impervious. The values coefficient of permeability in few bore holes is presented in Table 3. A total of 12 undisturbed soil samples and 18 SPT soil samples were collected from the bore holes drilled at head regulator, $\mathrm{CD}$ work sites and out fall site.

Table 2: SPT Values

\begin{tabular}{|c|c|c|c|c|c|c|c|c|c|c|c|}
\hline \multirow{2}{*}{$\begin{array}{l}\text { Depth } \\
\text { (m) }\end{array}$} & \multicolumn{11}{|c|}{ SPT Value } \\
\hline & $\begin{array}{l}\text { Bore } \\
\text { Hole -2 }\end{array}$ & $\begin{array}{l}\text { Bore } \\
\text { Hole }-4\end{array}$ & $\begin{array}{l}\text { Bore } \\
\text { Hole }-5\end{array}$ & $\begin{array}{l}\text { Bore } \\
\text { Hole }-6\end{array}$ & $\begin{array}{l}\text { Bore } \\
\text { Hole }-7\end{array}$ & $\begin{array}{l}\text { Bore } \\
\text { Hole-9 }\end{array}$ & $\begin{array}{l}\text { Bore } \\
\text { Hole-10 }\end{array}$ & $\begin{array}{l}\text { Bore } \\
\text { Hole-11 }\end{array}$ & $\begin{array}{l}\text { Bore } \\
\text { Hole }-12\end{array}$ & $\begin{array}{l}\text { Bore } \\
\text { Hole }-13\end{array}$ & $\begin{array}{l}\text { Bore } \\
\text { Hole }-14\end{array}$ \\
\hline 1.54 & - & $>50$ & - & - & - & $>50$ & $>50$ & 11 & - & - & - \\
\hline 1.95 & $>50$ & & $>50$ & $>50$ & 14 & - & - & - & $>50$ & $>50$ & $>50$ \\
\hline 3.00 & $>50$ & $>50$ & & & 14 & $>50$ & - & - & - & - & - \\
\hline 3.45 & & - & $>50$ & $>50$ & - & - & 4 & 4 & 19 & 9 & $>50$ \\
\hline 4.00 & $>50$ & - & & & - & - & - & - & - & - & \\
\hline 4.50 & - & - & $>50$ & $>50$ & - & - & $>50$ & - & - & - & Refusal \\
\hline 4.95 & - & - & & & - & - & & 22 & $>50$ & $>50$ & - \\
\hline
\end{tabular}


Geotechnical Investigations For The Foundation Investigations At The Cross Drainage Structures Along The Canal Alignment For The Ponnaiyar-Palar Intra State Link Canal Project

\begin{tabular}{|l|l|l|l|l|l|l|l|l|l|l|l|}
\hline 6.00 & $>50$ & - & $>50$ & $>50$ & - & - & $>50$ & - & - & - & Refusal \\
\hline 6.45 & - & - & - & - & - & - & & 3 & - & $>50$ & - \\
\hline 7.00 & - & - & - & - & - & - & & - & - & - & - \\
\hline 7.50 & - & - & - & - & - & - & $>50$ & - & - & - & - \\
\hline
\end{tabular}

Table 3: Insitu Permeability Test Results

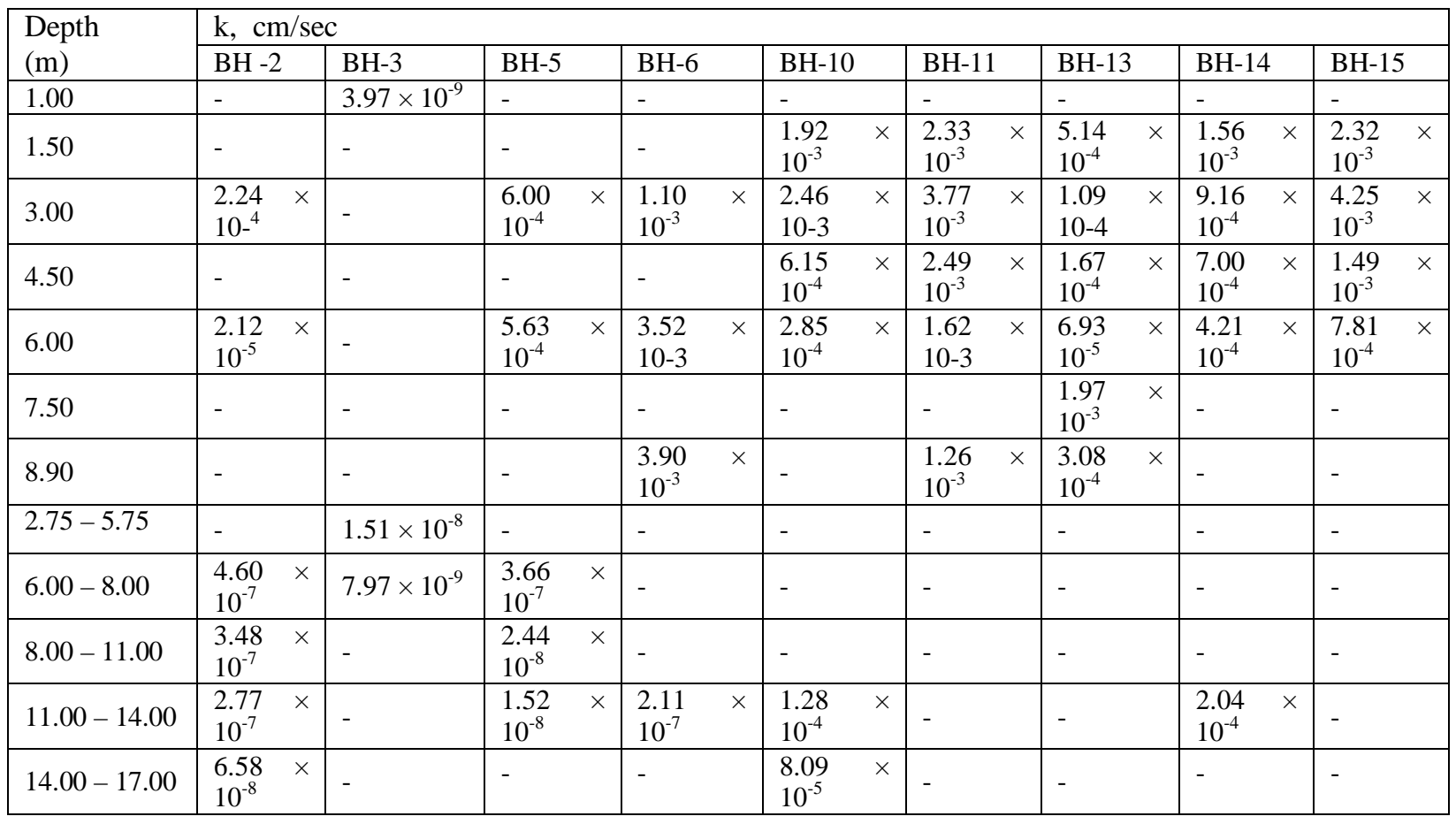

\section{LABORATORY INVESTIGATIONS}

All the 30 soil samples (12 undisturbed and 18 SPT soil samples) collected from the 11 bore holes at the cross drainage structure sites along the canal alignment were subjected to the following laboratory tests

\section{Mechanical Analysis and Atterberg Limits}

All the 30 soil samples (12 undisturbed and 18 SPT soil samples) were subjected to Mechanical Analysis and Atterberg limits tests. The grain size analysis of the tested soil samples indicate that the tested soil samples possess predominantly medium sand sizes followed by fine sand sizes and silt sizes. The grain sizes of the tested soil samples indicate that the clay sizes were totally absent in 5 soil samples and in the remaining 25 soil samples, the clay sizes vary from $0.1 \%$ to $37.6 \%$, silt sizes vary from $0.3 \%$ to $64.1 \%$, fine sand sizes vary from $1.6 \%$ to $36.8 \%$ and the medium sand sizes vary from $0.5 \%$ to $66.9 \%$ respectively. The coarse sand sizes were absent in 2 soil samples and in the remaining 28 soil samples, the coarse sand sizes vary from $1.1 \%$ to $47.4 \%$. The gravel size were totally absent in 11 soil samples and in the remaining 19soil samples the gravel sizes vary from $0.3 \%$ to $63.9 \%$. The graphical representations of grain size distribution of the tested soil samples from few bore holes are presented in Figures 3 (a) \& (b). 


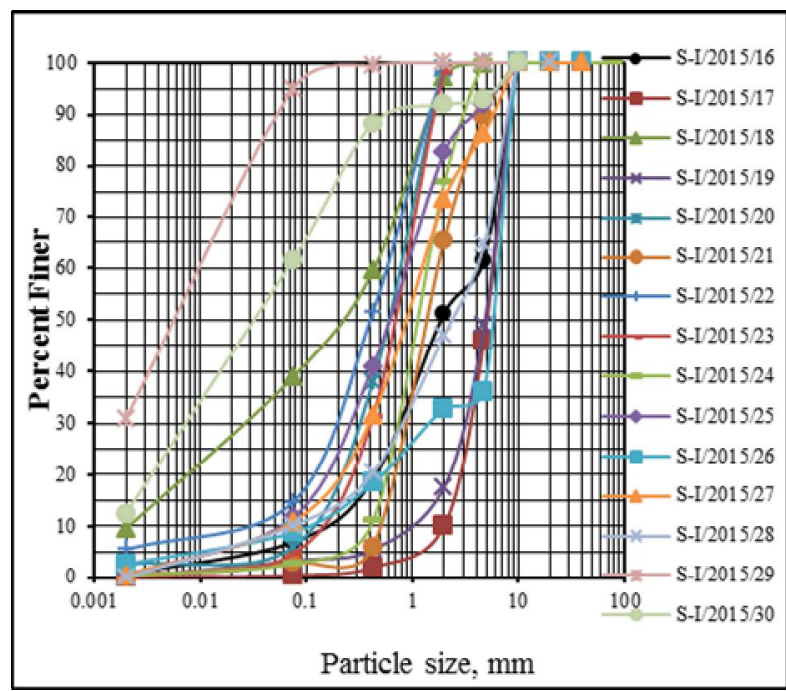

(a)

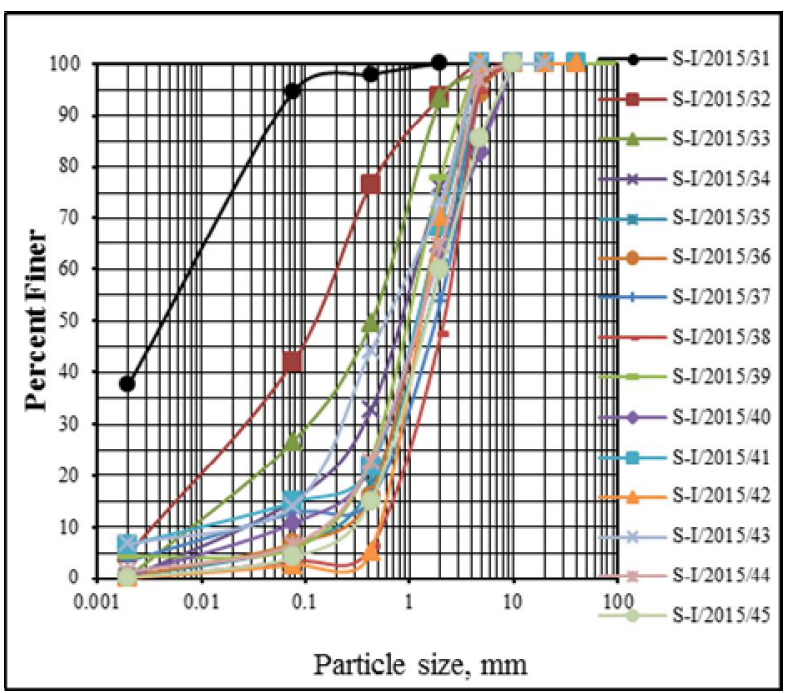

(b)

Figure 3 : Grain Size Distribution Curve (a) Bore Holes 1-10 (b) Bore Holes 11-15

The plasticity index values of the tested soil samples indicate that out of the 30 tested soil samples, 8 soil samples possess low to medium plasticity characteristics and the remaining 22 soil samples exhibit non plasticity characteristics.

Based on the results of grain size distribution and Atterberg limits tests, out of the 30 tested soil samples, 9 soil samples fall under SW-SM (Well graded Silty Sand), 5 soil samples fall under SC (Clayey Sand), 4 soil samples fall under SP (Poorly Graded Sand), 3 soil samples fall under SM (Silty Sand), 2 soil samples each fall under CI (Clay of Medium Compressibility) and SW (Well Graded Sand) respectively and out of the remaining 5 tested soil samples, one soil sample each falls under GP-GM (Poorly Graded Silty Gravel), GW (Well Graded Gravel), GP (Poorly Graded Gravel), SP-SM (Poorly Graded Silty Sand) and CL (Clay of Low Compressibility) groups respectively according to the Bureau of Indian Standard Soil Classification System.

\section{Insitu Density and Natural Moisture Content}

Nine undisturbed soil samples were subjected to the insitu density and natural moisture content tests. The values of insitu dry density and natural moisture content of the tested soil samples vary from $1.49 \mathrm{~g} / \mathrm{cc}$ to $1.89 \mathrm{~g} / \mathrm{cc}$ and $3.8 \%$ to $16.7 \%$ respectively. The test results of insitu density and natural moisture content for the tested soil samples are presented in Table -4.

\section{Table 4 : Insitu Density Test Results (CD Structures)}

\begin{tabular}{|l|l|l|l|l|l|l|}
\hline & & & \multicolumn{3}{|l|}{ Insitu Density and Natural Moisture Content } & \\
\cline { 3 - 6 } $\begin{array}{l}\text { RD } \\
(\mathrm{km})\end{array}$ & $\begin{array}{l}\text { Bore Hole } \\
\text { no. }\end{array}$ & $\begin{array}{l}\text { Depth } \\
(\mathrm{m})\end{array}$ & $\begin{array}{l}\text { Insitu Bulk } \\
\text { Density } \\
\mathrm{g} / \mathrm{cc}\end{array}$ & $\begin{array}{l}\text { Insitu Dry } \\
\text { Density } \\
\mathrm{g} / \mathrm{cc}\end{array}$ & $\begin{array}{l}\text { Natural } \\
\text { Moisture } \\
\text { Content } \\
\%\end{array}$ & $\begin{array}{l}\text { Specific } \\
\text { Gravity }\end{array}$ \\
\hline 29.642 & BH-4 & $1.50-1.90$ & 1.976 & 1.835 & 7.7 & 2.66 \\
\hline 45.518 & BH-6 & $1.50-1.90$ & 1.714 & 1.640 & 4.5 & 2.64 \\
\hline 45.518 & BH-6 & $4.50-4.90$ & 1.720 & 1.630 & 5.5 & 2.69 \\
\hline
\end{tabular}


Geotechnical Investigations For The Foundation Investigations At The Cross Drainage Structures Along The Canal Alignment For The Ponnaiyar-Palar Intra State Link Canal Project

\begin{tabular}{|l|l|l|l|l|l|l|}
\hline 42.395 & BH-10 & $1.50-1.95$ & 2.026 & 1.864 & 8.7 & 2.70 \\
\hline 42.890 & BH-11 & $1.50-1.95$ & 1.759 & 1.507 & 16.7 & 2.69 \\
\hline 42.890 & BH-11 & $3.00-3.45$ & 1.675 & 1.490 & 12.4 & 2.70 \\
\hline 36.108 & BH-12 & $4.50-4.95$ & 2.086 & 1.889 & 10.4 & 2.66 \\
\hline 35.049 & BH-13 & $1.50-1.95$ & 1.792 & 1.726 & 3.8 & 2.68 \\
\hline 35.049 & BH-13 & $4.50-4.95$ & 2.036 & 1.848 & 10.2 & 2.67 \\
\hline
\end{tabular}

\section{Triaxial Shear}

Three selected undisturbed soil samples from different bore holes were subjected to Consolidated Undrained Triaxial Shear tests with pore water pressure measurement. The undisturbed soil samples were consolidated and sheared under four different constant effective confining pressures of 1, 2, 3 and 4 $\mathrm{kg} / \mathrm{cm}^{2}$ respectively after achieving full saturation by back pressure. The total shear strength parameters total cohesion (c) and total angle of shearing resistance $(\phi)$ of the tested soil samples vary from 0.17 $\mathrm{kg} / \mathrm{cm}^{2}$ to $0.26 \mathrm{~kg} / \mathrm{cm}^{2}$ and $20.5^{\circ}$ to $25.1^{\circ}$ respectively. The effective shear strength parameters effective cohesion $\left(c^{\prime}\right)$ and effective angle of shearing resistance $\left(\phi^{\prime}\right)$ of the tested soil samples vary from 0.06 $\mathrm{kg} / \mathrm{cm}^{2}$ to $0.16 \mathrm{~kg} / \mathrm{cm}^{2}$ and $24.2^{\circ}$ to $31.2^{\circ}$ respectively. The results of Triaxial Shear tests - Consolidated Undrained with pore water pressure measurement of the tested soil samples are presented in Table -5 .

\section{Direct Shear}

Two selected undisturbed soil samples from different bore holes were subjected to direct shear test using small size shear box $(6 \mathrm{~cm} \times 6 \mathrm{~cm})$. The material was tested at insitu dry density, saturated and sheared under four different normal stresses of $1.0,2.0,3.0$ and $4.0 \mathrm{~kg} / \mathrm{cm}^{2}$ respectively. The shear strength parameters effective cohesion $\left(c^{\prime}\right)$ and total angle of shearing resistance $\left(\phi^{\prime}\right)$ of the tested soil samples vary from $0.0 \mathrm{~kg} / \mathrm{cm}^{2}$ to $0.2 \mathrm{~kg} / \mathrm{cm}^{2}$ and $31.0^{\circ}$ to $34.0^{\circ}$ respectively.

\section{One Dimensional Consolidation}

Three selected soil samples from different bore holes were subjected to One Dimensional Consolidation test for ascertaining its consolidation and compressibility characteristics. All the soil samples weretested at different stress levels viz. $0.25,0.5,1.0,2.0,4.0$ and $8.0 \mathrm{~kg} / \mathrm{cm}^{2}$ respectively. The test results indicate that the tested soil samples exhibit low to medium compressibility characteristics. The consolidation test results are presented in Tables -6 to 7 .

Table 5 : Triaxial Shear Test Results

\begin{tabular}{|l|l|l|l|l|l|}
\hline \multirow{2}{*}{$\begin{array}{l}\text { Bore } \\
\text { Hole }\end{array}$} & \multirow{2}{*}{$\begin{array}{l}\text { RD } \\
\text { No. }\end{array}$} & \multicolumn{4}{|l|}{ Triaxial Shear Test } \\
\cline { 3 - 6 } & & $\begin{array}{l}\text { Total shear } \\
\text { parameter }\end{array}$ & $\begin{array}{l}\text { Effective shear } \\
\text { parameter }\end{array}$ \\
\cline { 3 - 6 } & & $\begin{array}{l}\mathrm{c} \\
\mathrm{kg} / \mathrm{cm}^{2}\end{array}$ & $\phi^{\circ}$ & $\begin{array}{l}\mathrm{c}^{\prime} \\
\mathrm{kg} / \mathrm{cm}^{2}\end{array}$ & $\phi^{\prime 0}$ \\
\hline BH- 6 & 45.518 & 0.17 & $25.1^{\circ}$ & 0.06 & $31.2^{\circ}$ \\
\hline
\end{tabular}

Table 6: Consolidation Test results, $C_{v}$

\begin{tabular}{|l|l|l|l|l|l|}
\hline \multirow{2}{*}{$\begin{array}{l}\mathrm{RD}, \\
\mathrm{km}\end{array}$} & \multicolumn{3}{|l|}{$\begin{array}{l}\text { Coefficient of Consolidation, } \mathrm{C}_{\mathrm{v}} \times \\
10^{-4} \mathrm{~cm}^{2} / \mathrm{kg}\end{array}$} \\
\cline { 2 - 6 } & \multicolumn{3}{|l}{ Stress level, $\mathrm{kg} / \mathrm{cm}^{2}$} \\
\cline { 2 - 6 } & $\begin{array}{l}0.25- \\
0.50\end{array}$ & $\begin{array}{l}\text { 1.50- } \\
1.0\end{array}$ & $\begin{array}{l}1.0- \\
2.0\end{array}$ & $2.0-4.0$ & $\begin{array}{l}4.0- \\
8.0\end{array}$ \\
\hline 29.042 & 8.11 & 5.36 & 3.54 & 2.63 & 2.07 \\
\hline
\end{tabular}




\begin{tabular}{|l|l|l|l|l|l|}
\hline BH -11 & 42.890 & 0.26 & $20.5^{\circ}$ & 0.16 & $24.2^{\circ}$ \\
\hline BH -13 & 35.049 & 0.24 & $22.7^{\circ}$ & 0.12 & $30.4^{\circ}$ \\
\hline
\end{tabular}

\begin{tabular}{|l|l|l|l|l|l|}
\hline 45.518 & 6.42 & 3.53 & 2.61 & 2.06 & 1.51 \\
\hline 36.108 & 2.67 & 2.11 & 1.56 & 1.23 & 1.00 \\
\hline
\end{tabular}

Table 7: Consolidation Test results, $\mathbf{m}_{v}, \mathbf{C}_{\mathrm{c}} \& \mathbf{C}_{\mathrm{s}}$

\begin{tabular}{|c|c|c|c|c|c|c|c|c|}
\hline \multirow{3}{*}{$\begin{array}{l}\text { Bore } \\
\text { Hole No. }\end{array}$} & \multirow{3}{*}{$\mathrm{RD}, \mathrm{km}$} & \multirow{2}{*}{\multicolumn{5}{|c|}{$\begin{array}{l}\begin{array}{l}\text { Coefficient of Volume Compressibility, } \mathrm{m}_{\mathrm{v}} \times 10^{-2} \\
\mathrm{~cm}^{2} / \mathrm{kg}\end{array} \\
\text { Stress level, } \mathrm{kg} / \mathrm{cm}^{2}\end{array}$}} & \multirow{3}{*}{$\begin{array}{l}\text { Compress- } \\
\text { ion Index, } \mathrm{C}_{\mathrm{c}}\end{array}$} & \multirow{3}{*}{$\begin{array}{l}\text { Swelling } \\
\text { Index, } C_{s}\end{array}$} \\
\hline & & & & & & & & \\
\hline & & $0.25-0.50$ & $0.50-1.0$ & $1.0-2.0$ & $2.0-4.0$ & $4.0-8.0$ & & \\
\hline BH- 4 & 29.042 & 1.73 & 0.85 & 0.46 & 0.31 & 0.27 & 0.0523 & 0.0140 \\
\hline BH- 6 & 45.518 & 2.18 & 1.18 & 0.67 & 0.46 & 0.26 & 0.0367 & 0.0117 \\
\hline BH- 12 & 36.108 & 2.94 & 1.14 & 0.71 & 0.47 & 0.29 & 0.0342 & 0.0098 \\
\hline
\end{tabular}

\section{CONCLUSIONS}

Based on the findings of the foundation investigations carried out at cross drainage structure alongthe alignment of proposed Ponnaiyar (Nedungal Anicut) - Palar Intra State Link Canal, Tamil Nadu, the following conclusions have been arrived at:

- Based on the SPT ' $\mathrm{N}$ ' values it may be inferred that the foundation strata in bore holes BH-1, BH-2, BH-4, BH-5, BH-6, BH-7, BH-9, BH-10, BH-12, BH-12, BH-13, BH-14 \& BH-15 possess high compactness and in bore holes $\mathrm{BH}-7$ \& $\mathrm{BH}-11$ foundation strata possess loose to medium compactness.

- Bases on the Insitu Permeability test, it may be inferred that foundation strata in bore holes BH-2, BH5, BH-6, BH-10, BH-1, BH-12, BH-13, BH-14 \& $\mathrm{BH}-15$ possess the pervious to semi pervious characteristics up to $6.00 \mathrm{~m}$ depth and in bore holes $\mathrm{BH}-1, \mathrm{BH}-3, \mathrm{BH}-4, \mathrm{BH}-7$ \& $\mathrm{BH}-9$ foundation strata possess the impervious characteristics up to $6.00 \mathrm{~m}$ depth. Beyond $6.00 \mathrm{~m}$ depth, the foundation strata in all bore holes possess the impervious characteristics except the bore holes BH-10, BH-11, BH-13\& BH-14 in which foundation strata possess the pervious to semi pervious characteristics.

- Based on the grain size analysis, it is inferred that the tested soil samples possess predominantly medium sand sizes followed by fine sand sizes and silt sizes.

- The plasticity index values of the tested soil samples indicate that the foundation strata in bore holes BH-2, BH-6, BH-7, BH-10, BH-12, BH-14, BH-15 possess low to medium plasticity characteristics and foundation strata in bore holes $\mathrm{BH}-4, \mathrm{BH}-11, \mathrm{BH}-7$ \& $\mathrm{BH}-13$ possess the plastic to non plastic characteristics.

- The values of Insitu Dry Density and Natural Moisture Content of the tested soil samples indicate that the foundation strata in general possess loose to medium compactness.

- The results of Triaxial Shear tests conducted on soil samples indicate that the foundation materials are likely to exhibit good shear strength characteristics.

- The results of Direct Shear tests conducted on soil samples indicate that the foundation materials are likely to exhibit good shear strength characteristics. 
- Based on the one dimensional consolidation test on the tested soil samples it is inferred that foundation materials are likely to undergo in general very low compressibility depending upon the imposed loads.

\section{ACKNOWLEDGEMENTS}

The authors are grateful to the Director, CSMRS for his support and encouragement during the investigations. The authors also acknowledge the contribution of CSMRS officers for their active involvement of investigations. The author also acknowledge the support and help extended by the NWDA to CSMRS team during the geotechnical investigations for the proposed Ponnaiyar (Nedungal Anicut) Palar Intra-State Link Project, Tamilnadu.

\section{REFERENCES}

[1]. CSMRS Report on "Foundation Investigations of Cross - Drainage Structures for the Proposed Ponnaiyar (Nedungal Anicut) - Palar Intra State Link Canal Project, Tamil Nadu”, (Report No. 05/Soil-I/Soil-I/CSMRS/E/07/2015, July 2015)

[2]. EM 1110-2-2300, (1982), Earth manual, Publication of United States Bureau of Reclamation

[3]. Fell, R., Macgregor, P., \& Stapledon, D. (1992), Geotechnical Engineering of Embankment dam

[4]. IS: 12169-1987: Criteria for Design of Small Embankments Dams.

[5]. IS:1498-1970 : Classification and Identification of Soils for general Purpose.

[6]. Master Thesis of Sharon Gourdji, Carrie Knowlton \& Kobi Platt "Indian Inter-linking of Rivers: A Preliminary Evaluation" 2005

[7]. Ministry of Water Resources, River Development and Ganga Rejuvenation official web site, http://wrmin.nic.in/

[8]. National Water Development Agency (NWDA), official web site, http:/nwda.gov.in/

[9]. SP-36 (Part-1)-1978: Standard Publication on Soil Testing in laboratory, Bureau of Indian Standards

[10]. Upali A. Amarasinghe, Bharat R. Sharma, Noel Aloysius, Christopher Scott, Vladimir Smakhtin and Charlotte de Fraiture "Spatial Variation in Water Supply and Demand across River Basins of India” IWMI 83, Research Report 